\title{
Importance of toothfish in the diet of generalist subantarctic killer whales: implications for fisheries interactions
}

\author{
Paul Tixier ${ }^{1,2, *}$, Joan Giménez ${ }^{3}$, Ryan R. Reisinger ${ }^{2,4}$, Paula Méndez-Fernandez ${ }^{5}$, \\ John P. Y. Arnould ${ }^{1}$, Yves Cherel ${ }^{2}$, Christophe Guinet ${ }^{2}$ \\ ${ }^{1}$ School of Life and Environmental Sciences (Burwood campus), Deakin University, Geelong, Victoria 3125, Australia \\ ${ }^{2}$ Centre d'Etudes Biologiques de Chizé (CEBC), UMR 7372 Université de la Rochelle-CNRS, 79360 Villiers-en-Bois, France \\ ${ }^{3}$ Institut de Ciències del Mar (ICM-CSIC), Passeig Marítim de la Barceloneta 27-49, 08003 Barcelona, Spain \\ ${ }^{4}$ CESAB-FRB, Bâtiment Henri Poincaré, Domain du Petit Arbois, Ave Louis Philibert, 13100 Aix-en-Provence, France \\ ${ }^{5}$ Observatoire PELAGIS, UMS 3462 du CNRS, Pôle Analytique, Université de la Rochelle, 5 allées de l'Océan, \\ 17000 La Rochelle, France
}

\begin{abstract}
Fisheries may generate new feeding opportunities for marine predators, which switch foraging behaviour to depredation when they feed on fish directly from fishing gear. However, the role of diet in the propensity of individuals to depredate and whether the depredated resource is artificial or part of the natural diet of individuals is often unclear. Using stable isotopes, this study investigated the importance of the commercially exploited Patagonian toothfish Dissostichus eleginoides in the diet of generalist subantarctic killer whales Orcinus orca depredating this fish at Crozet $\left(45^{\circ} \mathrm{S}, 50^{\circ} \mathrm{E}\right)$. The isotopic niche of these killer whales was large and overlapped with that of sperm whales Physeter macrocephalus from the same region, which feed on toothfish both naturally and through depredation. There was no isotopic difference between killer whales that depredated toothfish and those that did not. Isotopic mixing models indicated that prey groups including large/medium sized toothfish and elephant seal Mirounga leonina pups represented $\sim 60 \%$ of the diet relative to prey groups including penguins, baleen whales and coastal fish. These results indicate that toothfish are an important natural prey item of Crozet killer whales and that switching to depredation primarily occurs when fisheries facilitate access to that resource. This study suggests that toothfish, as a commercial species, may also have a key role as prey for top predators in subantarctic ecosystems. Therefore, assessing the extent to which predators use that resource naturally or from fisheries is now needed to improve both fish stock management and species conservation strategies.
\end{abstract}

KEY WORDS: Diet • Fisheries · Southern Ocean · Killer whale · Stable isotopes · Fishery interactions

\section{INTRODUCTION}

Anthropogenic activities may influence the dietary niche width of wild populations by modifying the availability of resources (Van Valen 1965, Newsome et al. 2015). While human activities often result in re-

\footnotetext{
${ }^{*}$ Corresponding author: p.tixier@deakin.edu.au
}

source scarcity, sometimes they generate new feeding opportunities for species (Votier et al. 2004, Woodroffe et al. 2005, Jennings et al. 2009). This is the case when predators feed on a resource that is either produced, raised or captured by humans (Woodroffe et al. 2005). This behaviour, defined as

(C) The authors 2019. Open Access under Creative Commons by Attribution Licence. Use, distribution and reproduction are unrestricted. Authors and original publication must be credited. 
'depredation', has been increasingly reported both in terrestrial (e.g. predators feeding on livestock; Sillero-Zubiri et al. 2007) and marine environments (e.g. predators feeding on fish raised in farms or caught in fishing gears; Northridge \& Hofman 1999, Gilman et al. 2007, 2008, Read 2008).

The depredated resource may already be part of the natural diet of predators, with access facilitated by humans, or it may be an entirely artificial resource which would not otherwise have been used by predators in natural conditions. This distinction is critical in understanding the underlying behavioural mechanisms of predators switching from a natural to a depredated resource (Boitani \& Powell 2012). Generalist predators may be more likely to depredate artificial new resources opportunistically while highly specialised predators may depredate a resource only if it is already part of their natural diet (Stoddart et al. 2001, Sidorovich et al. 2003). Knowing the importance of the depredated resource in the natural diet of predators is also needed to assess the effects of depredation and fisheries on wild populations, fish stocks and ecosystems as a whole. Depredation may substantially modify the energy balance of the predator and its role in ecosystem food web dynamics (Woodroffe et al. 2005). For instance, if the depredated resource is fully artificial for the predator, depredation may lead to decreased availability of that resource for other functional groups in the ecosystem, subsequently affecting these groups through trophic effects (Woodroffe et al. 2005). Also, by feeding on fish caught in fishing gear, marine predators may cause increased and difficult-to-quantify mortality for fish stocks, thereby increasing the catches needed for fisheries to reach their quotas (Gilman et al. 2013, Gasco et al. 2015, Mitchell et al. 2018).

In subantarctic waters, extensive commercial longline fisheries target economically highly valuable Patagonian toothfish Dissostichus eleginoides (hereafter 'toothfish'). These fisheries provide artificial feeding opportunities for a range of large marine predators through discards (primarily for albatrosses and petrels) and depredation (for odontocetes) (Tasker et al. 2000, Kock 2001, Kock et al. 2006). Toothfish are large $(0.5-2 \mathrm{~m})$ fish that dominate the biomass of the bathypelagic zone, but may also be found in the meso- and epi-pelagic zones (Collins et al. 2010). However, the role of toothfish in subantarctic ecosystems and their importance as a natural prey for predators is unclear (Cherel et al. 2000, 2017, Constable et al. 2000). Specifically, determining the extent to which predators naturally feed and rely on toothfish is critical to assess the impacts of exploitation of that resource by fisheries on the conservation of subantarctic predators, many of which are threatened or endangered (Croxall et al. 2012).

Killer whales Orcinus orca are one of the main species depredating toothfish from subantarctic longline fisheries (Kock et al. 2006). Unlike some other regions, where killer whales have highly specialised prey preferences (Similä et al. 1996, Ford et al. 1998, Foote et al. 2009), subantarctic populations have relatively broad dietary niches that include mammals, birds, fish and sometimes cephalopods (Guinet \& Jouventin 1990, Guinet 1992, Guinet et al. 2000, de Bruyn et al. 2013, Capella et al. 2014, Reisinger et al. 2016, Travers et al. 2018). This generalist diet may be driven by the subantarctic ecosystem's spatio-temporal heterogeneity in the availability of high-quality resources, such as seals, penguins and whales (Laws 1977, Knox 2006, Reisinger et al. 2018). This heterogeneity may force killer whales to supplement their primary diet with other prey such as fish and cephalopods. While toothfish are a confirmed depredated resource, there is no direct evidence of natural predation by killer whales on this fish species.

The killer whale population of the Crozet Islands (subantarctic islands located at $45^{\circ} \mathrm{S}, 50^{\circ} \mathrm{E}$ ), hereafter 'Crozet killer whales', is among the populations that have most extensively depredated toothfish from fisheries since the mid-1990s (Roche et al. 2007, Tixier et al. 2010, 2016, Guinet et al. 2015). Crozet killer whales prey on seals, penguins, baleen whales and small notothenioids in inshore waters (Guinet 1992, Guinet et al. 2000); not all individuals have switched to depredation on toothfish from fisheries (Tixier et al. 2015, 2017). Elucidating the extent to which these killer whales naturally rely on toothfish as a resource whose availability is modified by fisheries would therefore provide insights into the ecological mechanisms of prey switching to depredation. Critically, this information would clarify the role of these prey and predator species in subantarctic ecosystem food web dynamics and the impacts of fisheries on the conservation of predator populations and fish stocks. Therefore, using stable isotope and diet reconstruction analyses for Crozet killer whales, the aims of this study were to (1) assess the importance of toothfish relative to other prey items for Crozet killer whales, and compared with other Southern Ocean killer whale populations and odontocete species, and (2) examine variation in the dietary importance of toothfish across individuals of the same population, with respect to whether or not they depredated from fisheries. 


\section{MATERIALS AND METHODS}

\subsection{Species and sample collection}

Killer whale skin samples were collected at Crozet from biopsies performed remotely on free-ranging individuals, using a Barnett Rhino $150 \mathrm{lb}$ compound crossbow and custom-built darts (Ceta-Dart) equipped with sterilized stainless steel tips $(35 \mathrm{~mm}$ length, $7 \mathrm{~mm}$ diameter). Sampling was conducted opportunistically and passively (i.e. animals were not actively approached or followed using motorized means) from land on Possession Island and from a toothfish fishing vessel operating in the Crozet Exclusive Economic Zone (EEZ), from February 2011 to December 2012. Samples were collected from the mid-lateral region of the body, below the dorsal fin. Sub-samples containing skin tissue were stored in $70 \%$ ethanol. Only weaned individuals ( $>2 \mathrm{yr}$ old) were sampled. Sampling occurred only when a single individual surfaced within $15 \mathrm{~m}$ of the sampler, and only when this individual was positively identified by eye during surfacing events directly preceding sampling. The sequence made of multiple surfacing events and the sampling event was monitored by photographs and/or video. Photographs of the dorsal fin of the sampled individual were systematically taken using a DSLR camera with $400 \mathrm{~mm}$ telephoto lens, and were used to confirm the identity of that individual after sampling, using an existing photoidentification database (Tixier et al. 2014). An additional skin sample was obtained from an individual found stranded and dead on Possession Island on 17 August 2006. The individual was an apparently healthy sub-adult male (total length [TL]: $6.90 \mathrm{~m}$ ) which was known to be part of the Crozet killer whale population based on photo-identification records. However, because this sample was collected $5 \mathrm{yr}$ before the biopsy samples, at a different time of year (winter) and lacked information about the behaviour of the individual over the pre-sampling period, isotopic information for this sample was not included in the analyses.

Isotopic information from skin samples collected from the Crozet killer whales was first examined through large-scale comparisons with other isotopic information available for other killer whale populations and other large odontocete species with different feeding ecologies and/or different habitats in the Southern Ocean (south of the Subtropical Front, $\sim 40^{\circ} \mathrm{S}$ ). Published isotopic values for weaned killer whales ( $>2$ yr old) were obtained for one other subantarctic (Marion Island, $1000 \mathrm{~km}$ west of Crozet at a similar latitude) and 3 Antarctic populations (Types B1 and B2 around the Antarctic Peninsula [Durban et al. 2017] and Type $C$ in the Ross Sea [Pitman \& Ensor 2003]). The isotopic niche of the Crozet killer whales was expected to be similar to that of killer whales at Marion, as the 2 populations share similar habitats and appear to have a generalist feeding strategy based on consumption of the same prey species (Reisinger et al. 2016). In contrast, Antarctic killer whales, which use a different habitat and specialise on either fish (Type $C_{i}$ Pitman \& Ensor 2003, Krahn et al. 2008), krill consumers (e.g. pygoscelid penguins) (Type B2; Pitman \& Durban 2010) or predators of krill consumers, such as Weddell seals Leptonychotes weddellii (Type B1; Pitman \& Durban 2012, Durban et al. 2017), were expected to have limited isotopic overlap with the Crozet killer whales. Isotopic information was also compared with that of sperm whales Physeter macrocephalus, which also depredate toothfish on longline fisheries, and southern long-finned pilot whales Globicephala melas edwardii from populations using similar habitats to that of the Crozet killer whales at Crozet and/or adjacent waters. Sperm whale skin samples were collected from fishing vessels operating in the Crozet and Kerguelen EEZs in January and February 2011, using the same equipment and protocols, and were treated using the same process as for the Crozet killer whale samples. For southern long-finned pilot whales, whose pelagic habitat overlaps with areas where toothfish fisheries operate but were never observed depredating toothfish on longlines, published skin isotopic values from weaned individuals ( $>3 \mathrm{~m}$ in length) at Kerguelen were used (Fontaine et al. 2015).

Species were considered confirmed prey for the Crozet killer whales if predation was directly observed and/or remains were found in the stomach contents of the individual found dead in 2006 (Table S1 in Supplement 1 at www.int-res.com/ articles/suppl/m613p197_supp.pdf). From these data, species confirmed as prey items and for which spring/summer isotopic values were available for the study at Crozet included southern elephant seals Mirounga leonina (adult females and pups, confirmed as prey from observations and stomach contents); Antarctic and subantarctic fur seals Arctocephalus gazella and A. tropicalis (pups, from stomach contents); king penguins Aptenodytes patagonicus, gentoo penguins Pygoscelis papua, macaroni penguins Eudyptes chrysolophus, rockhopper penguins E. chrysocome filholi (all adults, from observations and stomach contents); and Patagonian toothfish (TL 81-174 cm, from observations) (Table 1). 
Table 1. Mean $\pm \mathrm{SD} \delta^{13} \mathrm{C}$ and $\delta^{15} \mathrm{~N}$ values for prey species and prey groups of the Crozet killer whale used in the MixSIAR models. Prey groups were determined via Ward's hierarchical clustering based on isotopic similarities. Prey species were differentiated based on age class (adults vs. juveniles; here, 'pups' for seal species), sex, season in which sampling occurred or size (total length [TL] for fish species) when relevant, and an abbreviation code is assigned to each. Sampling sites included Crozet Islands (CR), Kerguelen Islands (KE) and New Zealand (NZ). Isotopic values are provided for the type of tissue sampled: red blood cells (RBC), whole blood (WB), skin or muscle. These values were adjusted to represent muscle values for all prey species

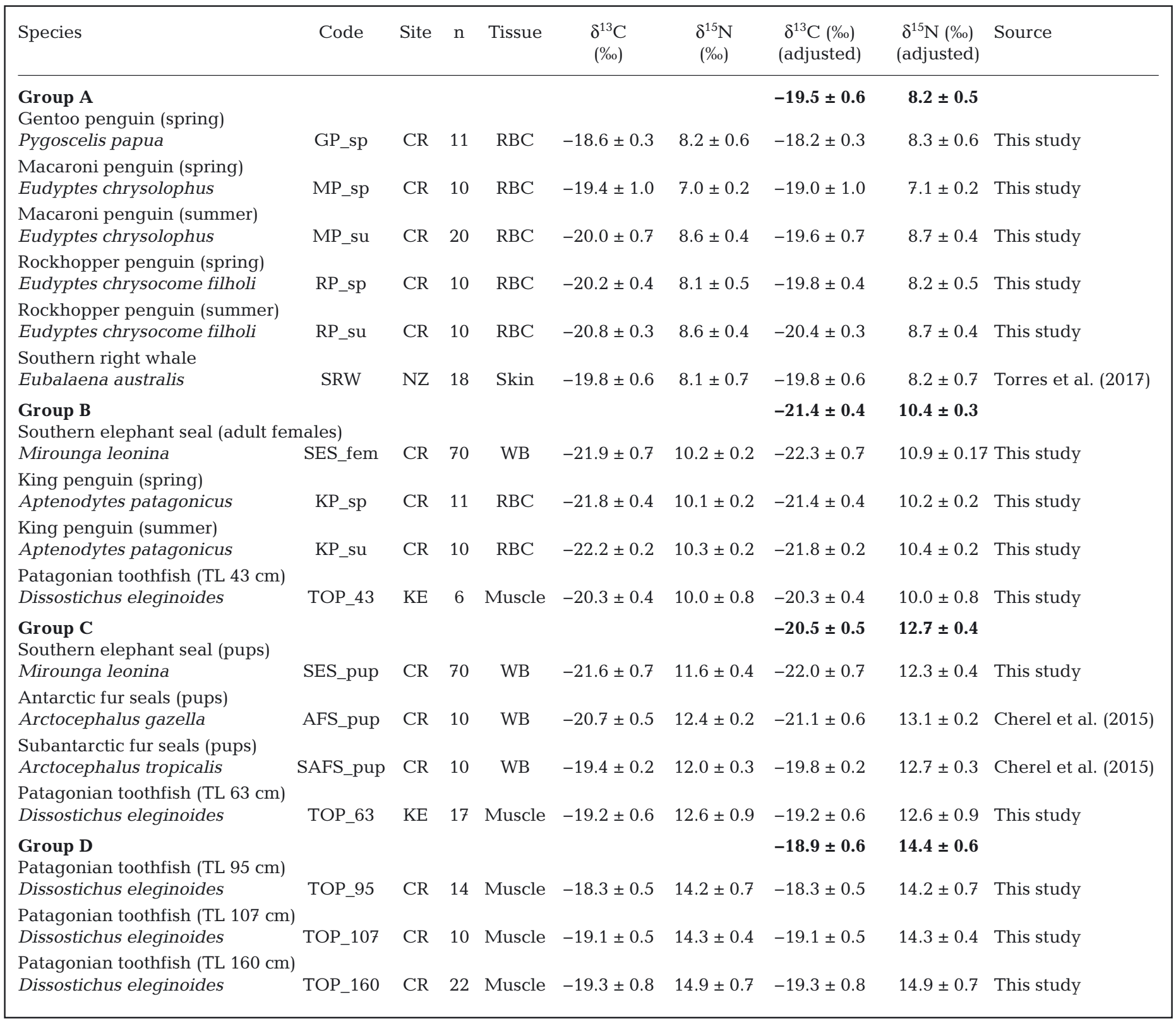

Additional Patagonian toothfish samples for small and medium size individuals (TL $38-71 \mathrm{~cm}$ ) were collected at Kerguelen (Table 1). For southern right whales Eubalaena australis (confirmed as prey from observations), isotopic values were from individuals sampled near subantarctic Campbell Island (Torres et al. 2017) (Table 1).

\subsection{Stable isotope analyses}

Killer whale skin samples were first oven-dried at $50^{\circ} \mathrm{C}$ for $48 \mathrm{~h}$ to allow ethanol evaporation, then ground and freeze-dried. As stable isotope values may be influenced by the lipid content of the tissue (Lesage et al. 2010, Giménez et al. 2017), 2 successive 
and identical lipid extractions were conducted using cyclohexane, each through $1 \mathrm{~h}$ sonication and subsequent centrifugation at $3000 \mathrm{rpm}$ (i.e. $1613 \times$ g). The lipid-extracted samples were then oven-dried again at $50^{\circ} \mathrm{C}$ for $48 \mathrm{~h}$ before being sub-sampled down to 0.3-0.4 mg. These sub-samples were processed at LIttoral ENvironnement et Sociétés (LIENSs; University of La Rochelle, France) through a continuous-flow isotope-ratio mass spectrometer (Micromass Isoprime) paired with an elemental analyser (Euro Vector EA 3024) for carbon and nitrogen isotope relative abundance $\left({ }^{13} \mathrm{C} /{ }^{12} \mathrm{C}\right.$ and ${ }^{15} \mathrm{~N} /{ }^{14} \mathrm{~N}$, respectively). The isotopic compositions are reported in the conventional $\delta$ notation as the per mil (\%o) deviation relative to the standards Vienna Peedee Belemnite (for carbon) and air (for nitrogen), expressed in parts per thousand (\%o). Within-run $(\mathrm{n}=10)$ replicate measurements of internal laboratory standards (acetanilide) indicated measurement errors $<0.15 \%$ for both $\delta^{13} \mathrm{C}$ and $\delta^{15} \mathrm{~N}$ values. Samples with a C:N mass ratio $<3.6$ were considered lipid-free (Yurkowski et al. 2015, Giménez et al. 2017) and included in subsequent analyses. Prey samples for which the analysed tissue was muscle (toothfish) were processed using the same protocol as for killer whale skin, including cyclohexane lipid extraction. For the other prey (elephant seals, fur seals and penguins), where isotopic values were measured for whole blood or red blood cells, values were adjusted to represent muscle using adjustment values presented in Reisinger et al. (2016). The isotopic method was validated in the southern Indian Ocean (encompassing the killer whale feeding areas), with $\delta^{13} \mathrm{C}$ values of consumers indicating their foraging habitats (Cherel \& Hobson 2007) and their $\delta^{15} \mathrm{~N}$ values increasing with trophic level (Cherel et al. 2010).

The isotopic niche width of the Crozet killer whale population was estimated and compared to other populations of killer whales, sperm whales and southern pilot whales within the Southern Ocean in a Bayesian framework using multivariate ellipse-based metrics (Jackson et al. 2011). Standard ellipse areas corrected for sample size $\left(\mathrm{SEA}_{\mathrm{c}}\right)$ and Bayesian Standard Ellipse Areas $\left(\mathrm{SEA}_{\mathrm{B}}\right)$ were calculated for each group. $\mathrm{SEA}_{B}$ was estimated using $10^{5}$ posterior draws and used to statistically compare niche metrics, which included niche width and niche overlap between groups. The niche overlap for 2 given groups was calculated as an isotopic area of overlap from the maximum likelihood fitted ellipses of the 2 groups (Jackson et al. 2011). All niche metric calculations and comparisons were conducted with the package 'SIBER' (Jackson et al. 2011) in R v.3.4.1 (R Development Core Team 2017).
The effect of toothfish depredation on the isotopic values of Crozet killer whales was examined through a 2-state index assigned to each sample. Samples were categorised as 'depredating' or 'non-depredating' depending on whether the biopsied individuals were observed interacting with fisheries in the 24 or $48 \mathrm{~d}$ preceding the sampling date. These 2 periods were defined based on isotopic half-time turnover rates estimated for bottlenose dolphin Tursiops truncatus skin: $24 \pm 8 \mathrm{~d}$ for carbon and $48 \pm 19 \mathrm{~d}$ for nitrogen (Giménez et al. 2016). Thus, depredating samples were samples from individuals that were photographed at least once while depredating toothfish caught by fishing vessels during the $24 \mathrm{~d}$ before sampling for $\delta^{13} \mathrm{C}$ analyses, and $48 \mathrm{~d}$ before sampling for $\delta^{15} \mathrm{~N}$ analyses. Photographs were taken from fishing vessels by fishery observers, who are present onboard licenced toothfish longliners for all fishing trips. They monitor $100 \%$ of the fishing operations and provide a quasi-systematic (on average $>95 \%$ of fishing days with killer whale presence around vessels covered) photo-identification effort during killer whale-fishing gear interaction events using DSLR cameras with $400 \mathrm{~mm}$ telephoto lenses. Non-depredating samples were samples from individuals for which the biopsy was performed when no fishing occurred in the Crozet EEZ 24 or $48 \mathrm{~d}$ before sampling, based on the PECHEKER database (Martin \& Pruvost 2007), or from individuals that were not photographed from fishing vessels 24 or $48 \mathrm{~d}$ before sampling. The absence of fishing vessels operating illegally inside and/or in the vicinity of the Crozet EEZ during the $48 \mathrm{~d}$ preceding biopsies was checked through satellite and ship-based surveillance data requested from the French administration. This ruled out the possibility that killer whales had depredated toothfish from vessels other than the ones from which we received data. Additionally, recent satellite/dive recorder data from a killer whale depredating toothfish at South Georgia indicated that depredation events only occurred in the vicinity of the vessel during gear retrieval phases, which is when observers provide photo-identification effort (Towers et al. 2019).

Niche metric comparisons and statistical tests performed on $\delta^{13} \mathrm{C}$ and $\delta^{15} \mathrm{~N}$ values were used to assess dietary variations between depredating and nondepredating samples. $\mathrm{SEA}_{c}$ and $\mathrm{SEA}_{\mathrm{B}}$ were calculated separately for depredating and non-depredating samples; here, this assignment was made using information on the occurrence of depredation in the $48 \mathrm{~d}$ preceding sampling. After the normality of the $\delta^{13} \mathrm{C}$ and $\delta^{15} \mathrm{~N}$ values was tested (Shapiro-Wilk test), 
differences between depredating and non-depredating groups were tested using either parametric $(t-$ test) or non-parametric (Mann-Whitney U-test) tests.

\subsection{Diet reconstruction}

The relative contribution of various prey items to the diet of the Crozet killer whales, and the influence of fishery interactions on this contribution, were assessed through Bayesian stable isotope mixing models fitted in the 'MixSIAR' package (Stock \& Semmens 2013, Stock et al. 2018) in R v.3.4.1 (R Development Core Team 2017). This analysis was conducted using prey data only for confirmed prey items, as described above. The mean stable isotope values of these species were used to a priori identify statistically different clusters through a Ward's hierarchical cluster analysis ('hclust' function in R package 'stats') and ANOVAs. MixSIAR models were fitted using the individual isotopic values of the Crozet killer whales (consumer), the mean \pm SD isotopic values of prey clusters (sources) and the diet-to-tissue discrimination factors (DTDF) estimated by Giménez et al. (2016) for bottlenose dolphin skin (DTDF for $\delta^{13} \mathrm{C}=1.01 \pm 0.37 \%$; $\delta^{15} \mathrm{~N}=1.57 \pm 0.52 \%$ ). Fishery interaction was incorporated in the MixSIAR models as a fixed effect using samples categorised as depredating or non-depredating based on the $48 \mathrm{~d}$ preceding sampling. The effect of depredating or nondepredating on the relative contribution of prey groups to killer whale diet was tested through model selection based on the leave-one-out information criterion (LOO ${ }_{\text {ic }}$ ) (Vehtari et al. 2017, Stock et al. 2018).
Models were run with a generalist type prior, 3 Markov chain Monte Carlo (MCMC) chains of 300000 draws and a burn-in of 200000 draws. The convergence of models was checked using both GelmanRubin and Geweke diagnostics. Model evaluation and validation were conducted by determining the likelihood of prey groups being included in the mixing polygon of the Crozet killer whales, based on simulations developed by Smith et al. (2013). Unless otherwise stated, data are presented as mean \pm SD.

\section{RESULTS}

Biopsy samples were obtained from 18 individuals from the Crozet killer whale population (Table S2 in Supplement 1). Values of $\delta^{13} \mathrm{C}$ of lipid-extracted skin ranged from -19.6 to $-18.0 \%$ and values of $\delta^{15} \mathrm{~N}$ from 12.5 to $14.3 \%$ (Table 2). Tests for potential age- and sex-effects on $\delta^{13} \mathrm{C}$ and $\delta^{15} \mathrm{~N}$ values indicated no significant differences between males $(\mathrm{n}=3)$ and females $(\mathrm{n}=15)$, nor between adults $(\mathrm{n}=14)$ and subadults $(\mathrm{n}=4)(t$-tests, all with $\mathrm{p}>0.5)$. Similarly, there were no significant differences between months of sampling ( $\mathrm{n}=9$ in February, $\mathrm{n}=6$ in November and $\mathrm{n}=3$ in December). The isotopic values of the skin sample collected from the individual found dead in 2006 were $\delta^{13} \mathrm{C}=-18.8 \%$ and $\delta^{15} \mathrm{~N}=13.4 \%$ o (Table S2).

\subsection{Stable isotope analyses}

The isotopic niche area of the Crozet killer whales, which was estimated at $\mathrm{SEA}_{\mathrm{C}}=0.64 \%{ }^{2}$ and $\mathrm{SEA}_{\mathrm{B}}=$

Table 2. Mean $\pm \mathrm{SD} \delta^{13} \mathrm{C}$ and $\delta^{15} \mathrm{~N}$ values of lipid-extracted skin and isotopic niche metrics for killer whales Orcinus orca, sperm whales Physeter macrocephalus and southern pilot whales Globicephala melas erwardii within the Southern Ocean. Niche metrics include the standard ellipse areas corrected for sample size $\left(\mathrm{SEA}_{C}\right)$ and the Bayesian $\mathrm{SEA}\left(\mathrm{SEA} \mathrm{A}_{\mathrm{B}}\right.$. SEA $\mathrm{S}_{\mathrm{B}} \mathrm{was}$ used to estimate the probability (Pr) of the Crozet killer whale isotopic niche being smaller than that of other groups $\left(\mathrm{Pr}<\mathrm{SEA}_{\mathrm{B}}\right)$, as well as the degree of overlap of isotopic niches (\% $\mathrm{SEA}_{\mathrm{B}}$ overlap)

\begin{tabular}{|c|c|c|c|c|c|c|c|c|}
\hline & $\mathrm{n}$ & $\delta^{13} \mathrm{C}(\%)$ & $\delta^{15} \mathrm{~N}(\%)$ & $\begin{array}{l}\mathrm{SEA}_{\mathrm{c}} \\
\left(\%{ }^{2}\right)\end{array}$ & $\begin{array}{l}\mathrm{SEA}_{\mathrm{B}} \\
\left(\% \mathrm{o}^{2}\right)\end{array}$ & $\begin{array}{c}\quad \mathrm{Pr} \\
<\mathrm{SEA}_{\mathrm{B}}\end{array}$ & $\begin{array}{l}\% \mathrm{SEA}_{\mathrm{B}} \\
\text { overlap }\end{array}$ & Source \\
\hline \multicolumn{9}{|l|}{ Orcinus orca } \\
\hline Crozet Islands & 18 & $-19.0 \pm 0.5$ & $13.6 \pm 0.4$ & 0.64 & 0.57 & - & - & This study \\
\hline Marion Island & 32 & $-18.6 \pm 0.4$ & $12.3 \pm 0.6$ & 0.94 & 0.87 & 0.90 & 3 & Reisinger et al. (2016) \\
\hline Ross Sea (Type C) & 27 & $-23.8 \pm 0.4$ & $13.2 \pm 0.4$ & 0.21 & 0.2 & 0.00 & 0 & Krahn et al. (2008) \\
\hline Antarctic Peninsula (Type B1) & 11 & $-22.4 \pm 0.4$ & $12.2 \pm 0.4$ & 0.45 & 0.38 & 0.17 & 0 & Durban et al. (2017) \\
\hline Antarctic Peninsula (Type B2) & 8 & $-22.8 \pm 0.3$ & $11.3 \pm 0.2$ & 0.20 & 0.16 & 0.01 & 0 & Durban et al. (2017) \\
\hline \multicolumn{9}{|l|}{ Physeter macrocephalus } \\
\hline Crozet Islands/Kerguelen Islands & 6 & $-18.6 \pm 0.4$ & $14.0 \pm 0.4$ & 0.70 & 0.51 & 0.49 & 24 & This study \\
\hline \multicolumn{9}{|l|}{ Globicephala melas edwardii } \\
\hline Kerguelen Islands & 65 & $-18.4 \pm 0.5$ & $12.2 \pm 0.3$ & 0.36 & 0.40 & 0.07 & 0 & Fontaine et al. (2015) \\
\hline
\end{tabular}




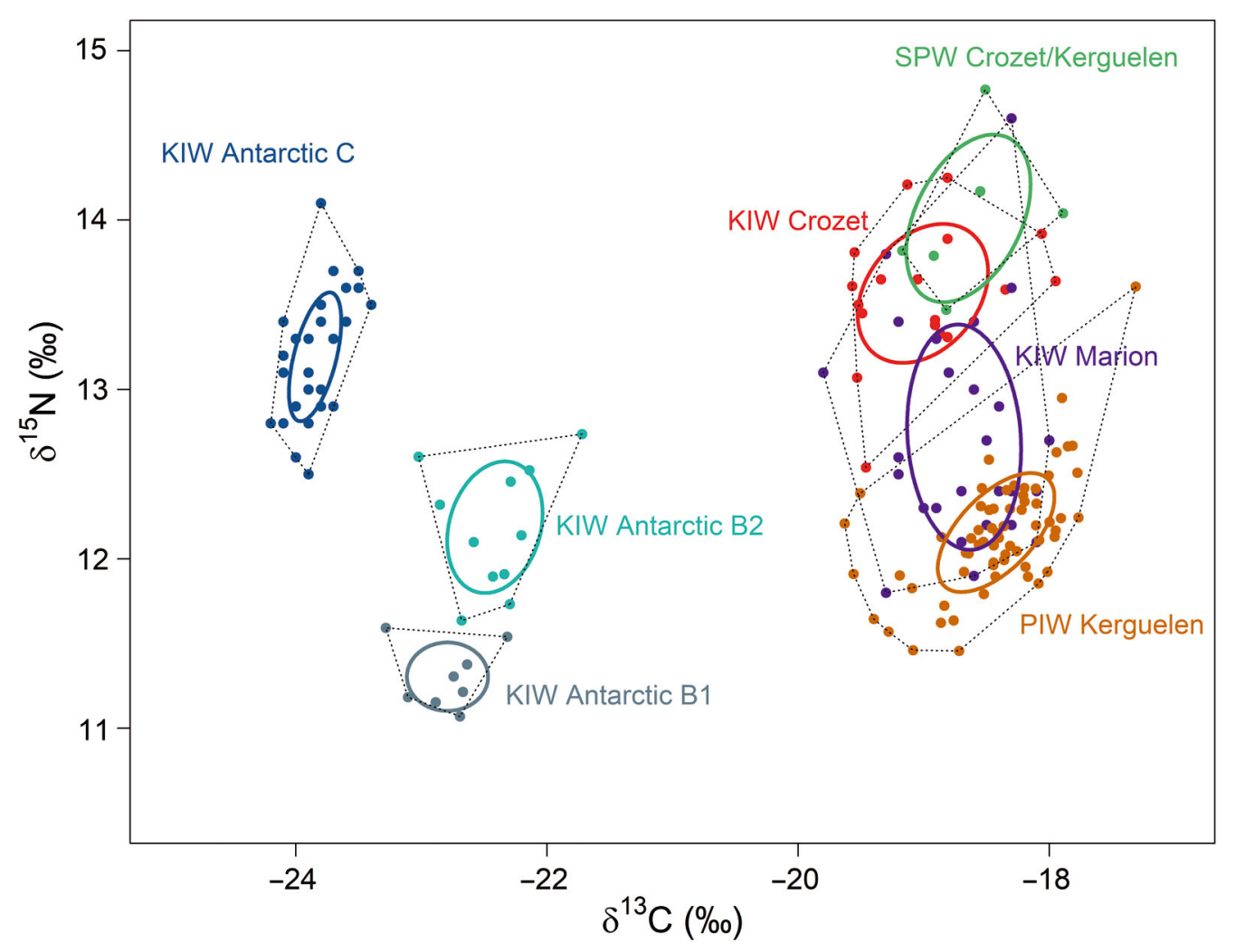

Fig. 1. Sample-size corrected standard ellipse areas (SEA ci solid lines) and convex hull areas (dotted lines) for killer whales (KIW), sperm whales (SPW) and southern pilot whales (PIW) in Antarctic and subantarctic waters. Individual values of $\delta^{13} \mathrm{C}$ and $\delta^{15} \mathrm{~N}$ of skin samples (points) for Crozet (this study), Marion (Reisinger et al. 2016), Antarctic Type C (Krahn et al. 2008), Antarctic Type B1 and B2 (Durban et al. 2017) killer whales, sperm whales from Crozet/Kerguelen (this study) and southern pilot whales from Kerguelen (Fontaine et al. 2015) are shown

$0.57 \%^{2}$, had a high probability of being smaller than that of the Marion killer whales $\left(\mathrm{SEA}_{\mathrm{C}}=0.94 \%{ }^{2}\right.$ and $\mathrm{SEA}_{\mathrm{B}}=0.87 \%{ }^{2}$ ), but was likely larger than those of Type B1, B2 and C killer whales sampled in Antarctica, and southern pilot whales from Kerguelen waters (Table 2, Fig. 1). However, with a probability of 0.49, the isotopic niche width of the Crozet killer whales was statistically similar to that of sperm whales sampled in Crozet and Kerguelen waters. Niche overlap of the Crozet killer whales was zero with Antarctic killer whales and Kerguelen southern pilot whales, low with the Marion killer whales (3\%) and highest with the Crozet and Kerguelen sperm whales $(24 \%)$.

In total, 9 of the sampled killer whales were sighted depredating toothfish from fisheries during the $24 \mathrm{~d}$ preceding sampling, and these samples were thus considered as depredating for $\delta^{13} \mathrm{C}$ comparisons (Tables S2 \& S4 in Supplement 1). Values of $\delta^{13} \mathrm{C}$ of these samples $\left(\delta^{13} \mathrm{C}=-19.0 \pm 0.7 \%\right.$, $\left.\mathrm{n}=9\right)$ were not significantly different (Mann-Whitney $U$-test, $\mathrm{p}=0.57$ ) from those of non-depredating samples $\left(\delta^{13} \mathrm{C}=-19.0\right.$ $\pm 0.3 \%, \mathrm{n}=9$ ). Values of $\delta^{15} \mathrm{~N}$ of samples from $11 \mathrm{in}$ dividuals sighted depredating from fisheries in the $48 \mathrm{~d}$ preceding sampling $\left(\delta^{15} \mathrm{~N}=13.4 \pm 0.4 \%\right.$, $\left.\mathrm{n}=11\right)$ were not statistically different from those of samples from individuals that did not depredate from fisheries over that period $\left(\delta^{15} \mathrm{~N}=13.8 \pm 0.4 \%, \mathrm{n}=7\right.$; $t$-test, $\mathrm{p}=$ 0.09). The isotopic niche area of non-depredating samples $\left(\mathrm{SEA}_{\mathrm{C}}=0.27\right.$ and $\left.\mathrm{SEA}_{\mathrm{B}}=0.16 \%^{2}\right)$ was likely smaller than that of depredating samples $\left(\mathrm{SEA}_{\mathrm{C}}=\right.$ 0.77 and $\mathrm{SEA}_{\mathrm{B}}=0.71 \%^{2}$ ) (Fig. S1 in Supplement 1).

\subsection{Diet reconstruction}

In total, 4 statistically different prey groups were identified from the Ward's hierarchical clustering of $\delta^{13} \mathrm{C}$ and $\delta^{15} \mathrm{~N}$ values (Figs. 2, 3a \& Fig. S2, Table S5 in Supplement 1). Group A included species with the lowest $\delta^{15} \mathrm{~N}$ values $(8.2 \pm 0.5 \%$ ): 3 species of penguins (Eudyptes spp. and gentoo penguins) and southern right whales (Table 1). Group B had a higher mean $\delta^{15} \mathrm{~N}$ value $\left(\delta^{15} \mathrm{~N}=10.4 \pm 0.4 \%\right.$ o $)$ and 


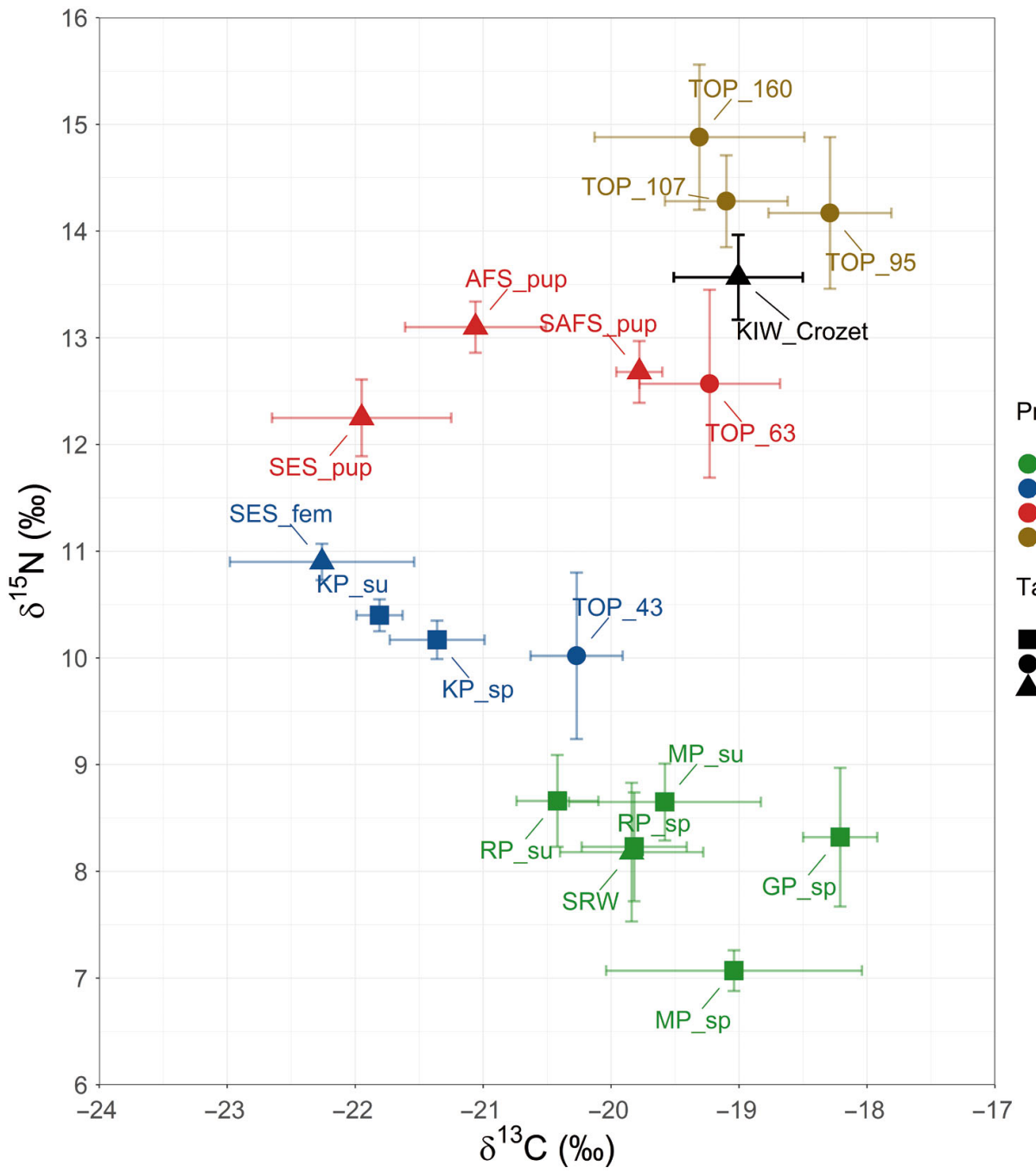

Prey group

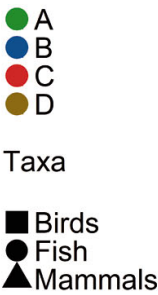

Fig. 2. Isospace of mean $( \pm \mathrm{SD})$ $\delta^{13} \mathrm{C}$ and $\delta^{15} \mathrm{~N}$ values of the putative prey items for the Crozet killer whales ('KIW_Crozet'). Colours indicate prey groups determined by a hierarchical clustering approach, and the shape of points indicate prey taxa. See Table 2 for species associated with the prey codes used for the figure

included king penguins, small sized Patagonian toothfish (TL $43 \mathrm{~cm}$ ) and the prey item with the lowest $\delta^{13} \mathrm{C}$ value, adult female southern elephant seals $\left(\delta^{13} \mathrm{C}=-21.9 \pm 0.7 \%\right.$, $\left.\mathrm{n}=70\right)$. Group $\mathrm{C}\left(\delta^{15} \mathrm{~N}=12.7 \pm\right.$ $0.4 \%$ ) contained medium sized toothfish (TL $63 \mathrm{~cm})$, elephant seal pups, Antarctic fur seals and subantarctic fur seals. Group D had the highest $\delta^{15} \mathrm{~N}$ $(14.4 \pm 0.6 \%)$ and $\delta^{13} \mathrm{C}(-18.9 \pm 0.6 \%)$ values and included only large (TL 95, 107 and $160 \mathrm{~cm}$ ) Patagonian toothfish. Toothfish of TL $160 \mathrm{~cm}$ was the prey item with the highest $\delta^{15} \mathrm{~N}$ value of all prey items $\left(\delta^{15} \mathrm{~N}=14.9 \pm 0.7 \%\right.$ o $)$.

All killer whale isotopic values were inside the $95 \%$ mixing region of the mixing polygon delimited by the isotopic values of the 4 prey groups adjusted to DTDFs, thus validating the MixSIAR models fitted with these prey groups (Fig. 3b). The best MixSIAR model (Model 1) included whether or not killer whales interacted with fisheries before sampling $\left(\mathrm{LOO}_{\text {ic }}=24.2\right.$; Table 3$)$. However, this model and the null model were differentiated by $\mathrm{LOO}_{\mathrm{ic}}=$ 0.1 , and the 2 models had close weights (0.51 and 0.49 , respectively), indicating that the depredation factor had low explanatory power. According to the null model, prey Group C was most important in the diet of Crozet killer whales with a mean contribution of $33 \pm 19 \%$ (Fig. 4a). Group D was the second most important prey group with $28 \pm 11 \%$ mean contribution. Group A and Group B were the least contributing prey groups with $17 \pm 7$ and $22 \pm 13 \%$, respectively. According to Model 1, Group C contributed $35 \pm 21 \%$ for depredating samples, and 33 $\pm 20 \%$ for non-depredating samples (Fig. 4b). The contribution of Group D to the diet of depredating samples was higher than for non-depredating samples (32 \pm 13 and $28 \pm 11 \%$, respectively). The diet of non-depredating samples included Group A and $\mathrm{B}$ in larger proportions $(17 \pm 7$ and $22 \pm 13 \%$, respectively) than for depredating samples (12 \pm 7 and $21 \pm 13 \%$, respectively). 

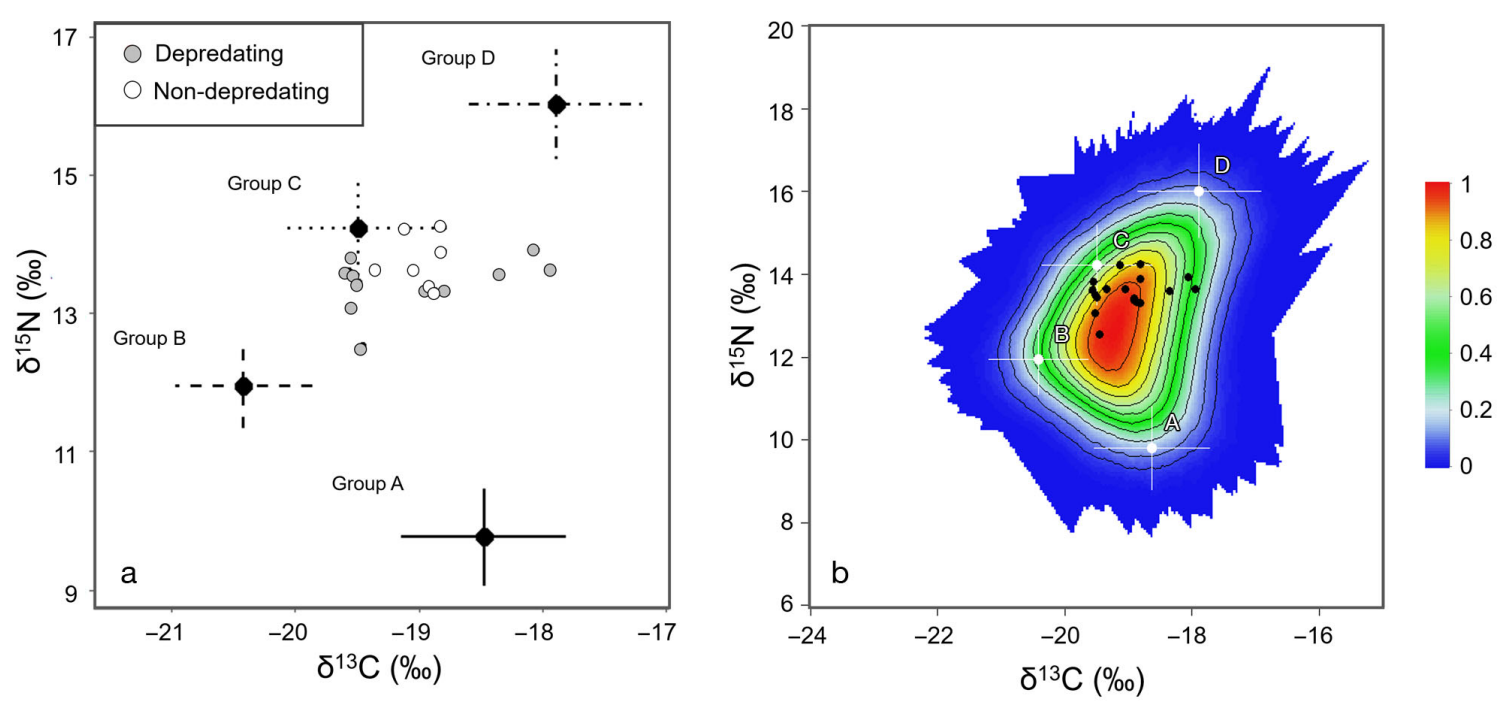

Fig. 3. (a) $\delta^{13} \mathrm{C}$ and $\delta^{15} \mathrm{~N}$ values of the skin samples of Crozet killer whales that depredated or did not depredate toothfish from fisheries before sampling, and mean with $95 \%$ confidence intervals of the putative prey groups (black dots and error bars) estimated from the source isotopic values and the diet-to-tissue discrimination factors. (b) Mixing polygon including the Crozet killer whale isotopic values (black dots) and prey groups (mean \pm SD isotopic value: white dots and error bars); background shows the probability of prey groups being included in the diet, with probability contours drawn every $10 \%$. Details on species included in prey groups are provided in Table 2

\section{DISCUSSION}

The present study provides key insights into the role of toothfish as a prey resource for a generalist subantarctic predator, the killer whale. The findings of different stable isotope analysis approaches, which combined inter- and intra-specific comparisons and dietary reconstruction, suggest that killer whales do rely on toothfish as well as marine mammals and penguins as natural prey items. While fisheries may facilitate access to toothfish for killer whales depredating on the fishing gear, fisheries also exploit toothfish stocks that are likely used by killer whales as a natural resource. This study therefore highlights the trophic interactions between fisheries and killer whales through depredation and competition for the same resource in subantarctic waters.

Table 3. MixSIAR model selection outputs based on leave-oneout cross validation information criterion $\left(\mathrm{LOO}_{\mathrm{ic}}\right)$. Models were fitted with the occurrence of depredation on toothfish from fisheries over the $48 \mathrm{~d}$ preceding sampling as a fixed effect ('Depredation'), or without any covariate ('Null'). The LOO $_{\text {ic }}$ differences between each model and the model with lowest $\mathrm{LOO}_{\mathrm{ic}}\left(\Delta \mathrm{LOO}_{\mathrm{ic}}\right)$, standard errors (SE) for both $\mathrm{LOO}_{\mathrm{ic}}$ and $\Delta \mathrm{LOO}_{\mathrm{ic}}$ values, as well as the relative weight of models are provided

\begin{tabular}{|llccccc|}
\hline $\begin{array}{l}\text { Model } \\
\#\end{array}$ & Model & $\mathrm{LOO}_{\mathrm{ic}}$ & $\begin{array}{c}\mathrm{SE} \\
\mathrm{LOO}_{\mathrm{ic}}\end{array}$ & $\Delta \mathrm{LOO}_{\mathrm{ic}}$ & $\begin{array}{c}\mathrm{SE} \\
\Delta \mathrm{LOO}_{\mathrm{ic}}\end{array}$ & Weight \\
\hline 1 & Depredation & 24.2 & 8.6 & - & - & 0.51 \\
2 & Null & 24.3 & 9.0 & 0.1 & 2.6 & 0.49 \\
\hline
\end{tabular}

Results of the stable isotope analyses confirmed previous visual observations suggesting that Crozet killer whales have a generalist feeding strategy. Their niche width was larger than that of specialised killer whale populations (Antarctic Type C, B1 and B2; Pitman \& Ensor 2003, Krahn et al. 2008, Pitman \& Durban 2010, 2012, Durban et al. 2017) but similar to that of Marion killer whales, another subantarctic population with a generalist feeding strategy (Reisinger et al. 2016). The Crozet killer whales were sampled in spring/summer and, during this time of year, the contribution of elephant seal pups to their diet was higher than that of prey groups including adult elephant seals, penguins and baleen whales. Recently weaned elephant seal pups are a concentrated and abundant high-quality food resource in inshore waters from October to January. While killer whales may favour elephant seal pups over other prey during that period, which is consistent with an increase in killer whale abundance in inshore waters in spring and summer (Guinet 1992), the importance of seals as prey throughout the year remains unknown. The fact that the stomach contents of the individual found dead on Possession Island in winter included elephant seal remains suggests that this resource may still be consumed during that time of year. While this suggestion is supported by skin isotopic values of that dead individual being similar to values from biopsy sam- 
a) Null model (all individuals)

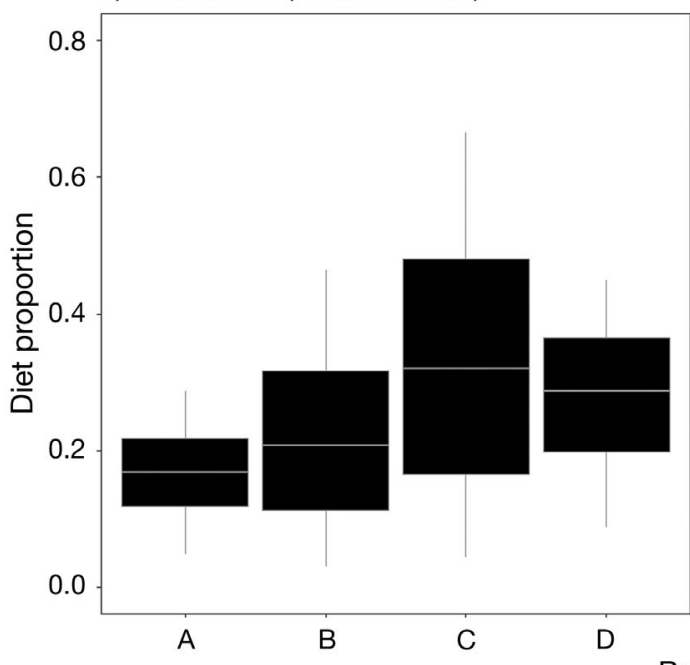

b) Model 1 (depredation before sampling)

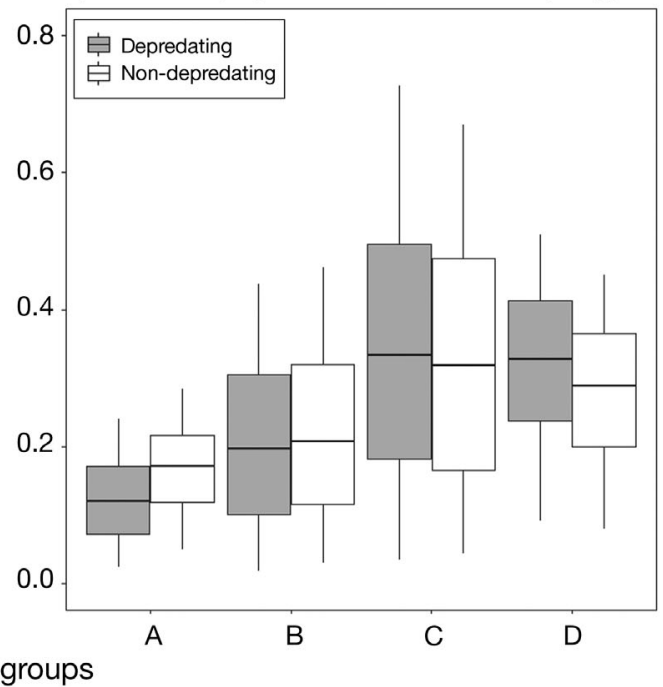

Fig. 4. Relative proportions of prey groups in the diet of (a) all Crozet killer whale samples and (b) samples from individuals that depredated toothfish from fisheries (depredating) or did not (non-depredating) $48 \mathrm{~d}$ before sampling. Diet proportions were estimated from the MixSIAR models (null model and Model 1) and are depicted as boxplots with the median (middle line), $25^{\text {th }}$ and $75^{\text {th }}$ percentiles (box hinges) and $95 \%$ confidence intervals (whiskers). Prey groups included the following items: Group A: gentoo, macaroni and rockhopper penguins and southern right whales; Group B: king penguins, elephant seals (adult females) and small Patagonian toothfish (TL $43 \mathrm{~cm}$ ); Group C: southern elephant seals (pups), Antarctic/ subantarctic fur seals (pups) and medium Patagonian toothfish (TL $63 \mathrm{~cm}$ ); Group D: large Patagonian toothfish (TL > $95 \mathrm{~cm}$ )

ples collected in spring/summer, also suggesting low seasonal variation in diet, additional samples collected in winter would be needed to further examine that aspect.

The 2 prey groups (C and D) including medium and large-sized Patagonian toothfish dominated the diet of Crozet killer whales (over $60 \%$ by mass when pooled, including nearly half from the group exclusively made of large toothfish). In addition, there was no difference in the contribution of these prey groups between depredating and non-depredating samples. The use of isotopic mixing models paired with the fact that none of the prey species included in our analysis also prey on toothfish ruled out the possibility of a secondary contamination effect. Instead, this result suggests that toothfish may be an important natural prey item for Crozet killer whales. This conclusion is supported by other lines of evidence. Firstly, subantarctic killer whales are able to dive to great depths ( $>1000 \mathrm{~m}$ at South Georgia; Towers et al. 2019) and they do so when foraging naturally (>750 $\mathrm{m}$ at Marion, >300 $\mathrm{m}$ at Crozet; Reisinger et al. 2015, G. Richard et al. unpubl. data). This depth range largely overlaps with the bathypelagic depth distribution of Patagonian toothfish, making them potentially naturally accessible to killer whales (Arkhipkin et al. 2003, Collins et al. 2010, Péron et al. 2016). Secondly, $\delta^{15} \mathrm{~N}$ values of the Crozet killer whales, as a proxy of trophic position, were similar to that of Antarctic Type C killer whales, which are known to feed preferentially on Antarctic toothfish Dissostichus mawsoni (Krahn et al. 2008), a species closely related to the Patagonian toothfish (Collins et al. 2010, Hanchet et al. 2015). Lastly, the isotopic niche of Crozet killer whales partly overlapped with that of sperm whales from Crozet and Kerguelen, which feed on both Patagonian and Antarctic toothfish both naturally (Yukhov 1972) and through depredation (Janc et al. 2018, Labadie et al. 2018) in Crozet and Kerguelen waters.

This study therefore suggests that depredation at Crozet is a facilitated behaviour in response to fisheries making toothfish an aggregated and easily accessible resource that killer whales would otherwise naturally forage on, but at higher energetic costs. By setting their gear at great depths, fisheries may provide killer whales with facilitated access to large toothfish $(>80 \mathrm{~cm})$, which are primarily found in waters $>800 \mathrm{~m}$ (Collins et al. 2010). This may explain the greater contribution of that prey group to the diet of depredating individuals. These findings are consistent with dietary studies on other depredating killer whale populations, such as in Gibraltar Strait, where facilitated access to bluefin tuna through depredation on fishing lines was found to be substantially less energetically costly than if this prey 
species was naturally and actively hunted (Guinet et al. 2007, Esteban et al. 2016).

More broadly, this study presents further evidence that toothfish have a key role as prey in subantarctic food web dynamics. While fisheries may facilitate access to toothfish for some predators, they may also impact populations that naturally depend on that resource through direct fish biomass removal. Toothfish has been confirmed as natural prey of sperm whales and sleeper sharks Somniosus antarcticus (Yukhov 1972, Cherel \& Duhamel 2004) and suggested as natural prey for meso- and epi-pelagic predators such as albatrosses (Cherel et al. 2000, 2017). While the commercial exploitation of toothfish stocks is now highly regulated, stocks underwent substantial illegal over-exploitation across the Southern Ocean in the 1990s that likely affected these apex predator species through direct trophic effects (Kock et al. 2007). The Crozet killer whales underwent a sharp decline in the 1990s and this was partly attributed to illegal fishers using lethal means to repel whales depredating toothfish (Poncelet et al. 2010, Tixier et al. 2015, 2017). However, from our results, it is likely that the illegal over-exploitation of toothfish stocks, paired with substantial decreases of southern elephant seals, king penguins and large whales (Guinet et al. 1992, Clapham et al. 1999, Weimerskirch et al. 2003, 2018, Pruvost et al. 2015), has also contributed to the decline of this population. Decreased toothfish availability may also have caused dietary shifts for killer whales in areas where stocks were depleted. For instance, killer whales at Marion Island were expected, from observations, to have large isotopic overlap with killer whales at Crozet (Reisinger et al. 2011), but this was not the case. The Marion killer whales are at a lower trophic level than the Crozet whales, and this difference may be explained by lower toothfish intake because toothfish stocks have been more impacted by illegal fishing at Marion than at Crozet (Boonzaier et al. 2012) (see Supplement 2 for further discussion).

In summary, this study has provided a preliminary assessment of the diet of killer whales that consume a wide range of subantarctic resources. However, determining the diet of a generalist predator is often hampered by temporal variations in prey consumption and limited information on prey. This is the case for cephalopods - their contribution to the diet could not be assessed in the present study (see Supplement 3 for further discussion). Therefore, further studies using higher resolution dietary methods, such as compound-specific stable isotope or fatty acid analyses (e.g. Herman et al. 2005, Matthews \& Ferguson 2014), are needed. Despite these limitations, the present study provided new insights on the role of natural prey preferences in the propensity of killer whales to switch prey in response to environmental changes. Specifically, our results support the assumption that killer whales are more likely to develop depredation on fisheries as a new foraging tactic if fish is already part of their natural diet. This assumption was proposed as explaining why not all killer whale populations, which greatly differ in prey preferences, switch from natural feeding to depredation despite large overlaps with fishing activity (e.g. Fearnbach et al. 2014, Peterson et al. 2014). The role of variation in prey preferences at the intra-population level, as reported in other killer whale populations (e.g. Samarra et al. 2017), should therefore be further examined with a larger sample size to understand the heterogeneity observed across groups/ individuals at Crozet in regards to depredation (Tixier et al. 2017). More importantly, our findings have emphasised the importance of toothfish, a species of high commercial value, in the natural diet of killer whales. However, the amount of toothfish that killer whales eat naturally compared to the toothfish biomass they remove from longlines when depredating is still unknown. This information is required for (1) assessing the minimum amount of toothfish biomass required to sustain killer whale populations, and (2) estimating the extent to which the depredated part of

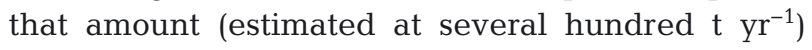
should be considered as natural or artificial mortality in fish stock assessments.

Acknowledgements. The authors thank the fieldworkers of Possession Island and the fishing vessel crews for their help in collecting tissue samples. Special thanks are due to Ghislain Doremus for retrieving stomach contents, and to Maxime Loubon and Frank Theron for assisting in biopsy sampling. We are also grateful to the fishery observers who collected sighting data from fishing vessels and to the Museum National d'Histoire Naturelle (Prof. Guy Duhamel, Nicolas Gasco and Charlotte Chazeau) for facilitating access to these data. We also thank Gael Guillou (LIENSs, La Rochelle), Marina Fontaine and Jeremy Kizska for helping with the stable isotope analysis. This work was conducted as part of the 109 program with the Institut Polaire Francais (IPEV). Funding and logistic support were provided by the Terres Australes et Antarctiques Francaises (TAAF), the Reserve Naturelle des Terres Australes, and the Reunion Island Fisheries Companies (SARPC) as part of the ORCADEPRED research program. P.T. and J.P.Y.A. were supported by the Australian Research Council (Linkage Project 160100329). R.R.R. and C.G. were supported by the International Whaling Commission's Southern Ocean Research Partnership. 


\section{LITERATURE CITED}

Arkhipkin A, Brickle P, Laptikhovsky V (2003) Variation in the diet of the Patagonian toothfish with size, depth and season around the Falkland Islands. J Fish Biol 63: 428-441

Boitani L, Powell RA (2012) Carnivore ecology and conservation: a handbook of techniques. Oxford University Press, Oxford

Boonzaier L, Harper S, Zeller D, Pauly D (2012) A brief history of fishing in the Prince Edward Islands, South Africa, 1950-2010. In: Harper S, Zylich K, Boonzaier L, Le Manach F, Pauly D, Zeller D (eds) Fisheries catch reconstructions: islands, Part II. Fisheries Centre Research Reports, Vol 20. Fisheries Center, University of British Columbia, Vancouver, p 95-101

Capella JJ, Abramson JZ, Vilina YA, Gibbons J (2014) Observations of killer whales (Orcinus orca) in the fjords of Chilean Patagonia. Polar Biol 37:1533-1539

Cherel Y, Duhamel G (2004) Antarctic jaws: cephalopod prey of sharks in Kerguelen waters. Deep Sea Res I 51: $17-31$

* Cherel Y, Hobson KA (2007) Geographical variation in carbon stable isotope signatures of marine predators: a tool to investigate their foraging areas in the Southern Ocean. Mar Ecol Prog Ser 329:281-287

* Cherel Y, Weimerskirch H, Trouvé C (2000) Food and feeding ecology of the neritic-slope forager black-browed albatross and its relationships with commercial fisheries in Kerguelen waters. Mar Ecol Prog Ser 207:183-199

Cherel Y, Fontaine C, Richard P, Labat JP (2010) Isotopic niches and trophic levels of myctophid fishes and their predators in the Southern Ocean. Limnol Oceanogr 55: 324-332

Cherel Y, Hobson KA, Guinet C (2015) Milk isotopic values demonstrate that nursing fur seal pups are a full trophic level higher than their mothers. Rapid Comm Mass Spectrom 29(16): 1485-1490

Cherel Y, Xavier JC, de Grissac S, Trouvé C, Weimerskirch H (2017) Feeding ecology, isotopic niche, and ingestion of fishery-related items of the wandering albatross Diomedea exulans at Kerguelen and Crozet Islands. Mar Ecol Prog Ser 565:197-215

Clapham PJ, Young SB, Brownell RL Jr (1999) Baleen whales: conservation issues and the status of the most endangered populations. Mammal Rev 29:37-62

Collins MA, Brickle P, Brown J, Belchier M (2010) The Patagonian toothfish: biology, ecology and fishery. Adv Mar Biol 58:227-300

Constable AJ, de la Mare WK, Agnew DJ, Everson I, Miller D (2000) Managing fisheries to conserve the Antarctic marine ecosystem: practical implementation of the Convention on the Conservation of Antarctic Marine Living Resources (CCAMLR). ICES J Mar Sci 57:778-791

* Croxall JP, Butchart SHM, Lascelles B, Stattersfield AJ, Sullivan B, Symes A, Taylor P (2012) Seabird conservation status, threats and priority actions: a global assessment. Bird Conserv Int 22:1-34

de Bruyn PJN, Tosh CA, Terauds A (2013) Killer whale ecotypes: Is there a global model? Biol Rev Camb Philos Soc 88:62-80

Durban JW, Fearnbach H, Burrows DG, Ylitalo GM, Pitman RL (2017) Morphological and ecological evidence for two sympatric forms of Type B killer whale around the Antarctic Peninsula. Polar Biol 40:231-236
Esteban R, Verborgh P, Gauffier P, Giménez J, Guinet C, de Stephanis R (2016) Dynamics of killer whale, bluefin tuna and human fisheries in the Strait of Gibraltar. Biol Conserv 194:31-38

*Fearnbach H, Durban JW, Ellifrit DK, Waite JM and others (2014) Spatial and social connectivity of fish-eating 'Resident' killer whales (Orcinus orca) in the northern North Pacific. Mar Biol 161:459-472

* Fontaine M, Carravieri A, Simon-Bouhet B, Bustamante P and others (2015) Ecological tracers and at-sea observations document the foraging ecology of southern longfinned pilot whales (Globicephala melas edwardii) in Kerguelen waters. Mar Biol 162:207-219

*Foote AD, Newton J, Piertney SB, Willerslev E, Gilbert MTP (2009) Ecological, morphological and genetic divergence of sympatric North Atlantic killer whale populations. Mol Ecol 18:5207-5217

Ford JK, Ellis GM, Barrett-Lennard LG, Morton AB, Palm RS, Balcomb KC III (1998) Dietary specialization in two sympatric populations of killer whales (Orcinus orca) in coastal British Columbia and adjacent waters. Can J Zool 76:1456-1471

Gasco N, Tixier P, Duhamel G, Guinet C (2015) Comparison of two methods to assess fish losses due to depredation by killer whales and sperm whales on demersal longlines. CCAMLR Sci 22:1-14

Gilman E, Brothers N, McPherson G, Dalzell P (2007) A review of cetacean interactions with longline gear. J Cetacean Res Manag 8:215-223

Gilman E, Clarke S, Brothers N, Alfaro-Shigueto J and others (2008) Shark interactions in pelagic longline fisheries. Mar Policy 32:1-18

*Gilman E, Suuronen P, Hall M, Kennelly S (2013) Causes and methods to estimate cryptic sources of fishing mortality. J Fish Biol 83:766-803

* Giménez J, Ramírez F, Almunia J, Forero MG, de Stephanis $\mathrm{R}$ (2016) From the pool to the sea: applicable isotope turnover rates and diet to skin discrimination factors for bottlenose dolphins (Tursiops truncatus). J Exp Mar Biol Ecol 475:54-61

* Giménez J, Ramírez F, Forero MG, Almunia J, de Stephanis R, Navarro J (2017) Lipid effects on isotopic values in bottlenose dolphins (Tursiops truncatus) and their prey with implications for diet assessment. Mar Biol 164:122

* Guinet C (1992) Comportement de chasse des orques (Orcinus orca) autour des iles Crozet. Can J Zool 70: 1656-1667

Guinet C, Jouventin P (1990) La vie sociale des "baleines tueuses". Recherche 220:508-510

Guinet C, Jouventin P, Weimerskirch H (1992) Population changes, movements of southern elephant seals on Crozet and Kerguelen Archipelagos in the last decades. Polar Biol 12:349-356

* Guinet C, Barrett-Lennard LG, Loyer B (2000) Co-ordinated attack behavior and prey sharing by killer whales at Crozet Archipelago: strategies for feeding on negativelybuoyant prey. Mar Mamm Sci 16:829-834

Guinet C, Domenici P, de Stephanis R, Barrett-Lennard L, Ford JKB, Verborgh P (2007) Killer whale predation on bluefin tuna: exploring the hypothesis of the enduranceexhaustion technique. Mar Ecol Prog Ser 347:111-119

Guinet C, Tixier P, Gasco N, Duhamel G (2015) Long-term studies of Crozet Island killer whales are fundamental to understanding the economic and demographic conse- 
quences of their depredation behaviour on the Patagonian toothfish fishery. ICES J Mar Sci 72:1587-1597

Hanchet S, Dunn A, Parker S, Horn P, Stevens D, Mormede S (2015) The Antarctic toothfish (Dissostichus mawsoni): biology, ecology, and life history in the Ross Sea region. Hydrobiologia 761:397-414

Herman DP, Burrows DG, Wade PR, Durban JW and others (2005) Feeding ecology of eastern North Pacific killer whales Orcinus orca from fatty acid, stable isotope, and organochlorine analyses of blubber biopsies. Mar Ecol Prog Ser 302:275-291

Jackson AL, Inger R, Parnell AC, Bearhop S (2011) Comparing isotopic niche widths among and within communities: SIBER-Stable Isotope Bayesian Ellipses in R. J Anim Ecol 80:595-602

Janc A, Richard G, Guinet C, Arnould JPY and others (2018) How do fishing practices influence sperm whale (Physeter macrocephalus) depredation on demersal longline fisheries? Fish Res 206:14-26

Jennings S, Kaiser M, Reynolds JD (2009) Marine fisheries ecology. Blackwell Science, Oxford

Knox GA (2006) Biology of the Southern Ocean. Cambridge University Press, Cambridge

Kock KH (2001) The direct influence of fishing and fisheryrelated activities on non-target species in the Southern Ocean with particular emphasis on longline fishing and its impact on albatrosses and petrels - a review. Rev Fish Biol Fish 11:31-56

Kock KH, Purves MG, Duhamel G (2006) Interactions between cetacean and fisheries in the Southern Ocean. Polar Biol 29:379-388

Kock KH, Reid K, Croxall J, Nicol S (2007) Fisheries in the Southern Ocean: an ecosystem approach. Philos Trans R Soc Lond B Biol Sci 362:2333-2349

Krahn MM, Pitman RL, Burrows DG, Herman DP, Pearce RW (2008) Use of chemical tracers to assess diet and persistent organic pollutants in Antarctic Type C killer whales. Mar Mamm Sci 24:643-663

Labadie G, Tixier P, Barbraud C, Fay R, Gasco N, Duhamel G, Guinet C (2018) First demographic insights on historically harvested and poorly known male sperm whale populations off the Crozet and Kerguelen Islands (Southern Ocean). Mar Mamm Sci 34:595-615

Laws RM (1977) Seals and whales of the Southern Ocean. Philos Trans R Soc Lond B Biol Sci 279:81-96

Lesage V, Morin Y, Rioux Ė, Pomerleau C, Ferguson SH, Pelletier É (2010) Stable isotopes and trace elements as indicators of diet and habitat use in cetaceans: predicting errors related to preservation, lipid extraction, and lipid normalization. Mar Ecol Prog Ser 419:249-265

Martin A, Pruvost P (2007) Pecheker, relational database for analysis and management of halieutic and biological data from the scientific survey of the TAAF fisheries. Muséum National d'Histoire Naturelle, Paris. https:// borea.mnhn.fr/pecheker

Matthews CJ, Ferguson SH (2014) Spatial segregation and similar trophic-level diet among eastern Canadian Arctic/north-west Atlantic killer whales inferred from bulk and compound specific isotopic analysis. J Mar Biol Assoc UK 94:1343-1355

Mitchell JD, McLean DL, Collin SP, Langlois TJ (2018) Shark depredation in commercial and recreational fisheries. Rev Fish Biol Fish 28:715-748

Newsome TM, Dellinger JA, Pavey CR, Ripple WJ, Shores CR, Wirsing AJ, Dickman CR (2015) The ecological effects of providing resource subsidies to predators. Glob Ecol Biogeogr 24:1-11

Northridge SP, Hofman RJ (1999) Marine mammal interactions with fisheries. In: Twiss JR, Reeves RR (eds) Conservation and management of marine mammals. Smithsonian Press, Washington, DC, p 99-119

* Péron C, Welsford DC, Ziegler P, Lamb TD and others (2016) Modelling spatial distribution of Patagonian toothfish through life-stages and sex and its implications for the fishery on the Kerguelen Plateau. Prog Oceanogr 141: 81-95

* Peterson MJ, Mueter F, Criddle K, Haynie AC (2014) Killer whale depredation and associated costs to Alaskan sablefish, Pacific halibut and Greenland turbot longliners. PLOS ONE 9:e88906

* Pitman RL, Durban JW (2010) Killer whale predation on penguins in Antarctica. Polar Biol 33:1589-1594

* Pitman RL, Durban JW (2012) Cooperative hunting behavior, prey selectivity and prey handling by pack ice killer whales (Orcinus orca), type B, in Antarctic Peninsula waters. Mar Mamm Sci 28:16-36

Pitman RL, Ensor P (2003) Three forms of killer whales (Orcinus orca) in Antarctic waters. J Cetacean Res Manag 5:131-140

Poncelet É, Barbraud C, Guinet C (2010) Population dynamics of killer whales (Orcinus orca) in the Crozet Archipelago, southern Indian Ocean: a mark-recapture study from 1977 to 2002. J Cetacean Res Manag 11:41-48

Pruvost P, Duhamel G, Gasco N, Palomares MD (2015) A short history of the fisheries of Crozet Islands. In: Palomares MLD, Pauly D (eds) Marine fisheries catches of subantarctic islands, 1950-2010. Fisheries Centre Research Reports, Vol 23. Fisheries Centre, University of British Columbia, Vancouver, p 31-37

R Development Core Team (2017) R: a language and environment for statistical computing. R Foundation for Statistical Computing, Vienna

* Read AJ (2008) The looming crisis: interactions between marine mammals and fisheries. J Mammal 89:541-548

* Reisinger RR, de Bruyn PJN, Tosh CA, Oosthuizen WC, Mufanadzo NT, Bester MN (2011) Prey and seasonal abundance of killer whales at sub-Antarctic Marion Island. Afr J Mar Sci 33:99-105

* Reisinger RR, Keith M, Andrews RD, de Bruyn PJN (2015) Movement and diving of killer whales (Orcinus orca) at a Southern Ocean archipelago. J Exp Mar Biol Ecol 473: 90-102

Keisinger RR, Gröcke DR, Lübcker N, McClymont EL, Hoelzel AR, de Bruyn PJN (2016) Variation in the diet of killer whales Orcinus orca at Marion Island, Southern Ocean. Mar Ecol Prog Ser 549:263-274

Reisinger RR, Raymond B, Hindell MA, Bester MN and others (2018) Habitat modelling of tracking data from multiple marine predators identifies important areas in the Southern Indian Ocean. Divers Distrib 24:535-550

Roche C, Guinet C, Gasco N, Duhamel G (2007) Marine mammals and demersal longline fishery interactions in Crozet and Kerguelen Exclusive Economic Zones: an assessment of depredation levels. CCAMLR Sci 14:67-82

* Samarra FP, Vighi M, Aguilar A, Víkingsson GA (2017) Intra-population variation in isotopic niche in herringeating killer whales off Iceland. Mar Ecol Prog Ser 564: 199-210

Sidorovich VE, Tikhomirova LL, Jędrzejewska B (2003) Wolf Canis lupus numbers, diet and damage to livestock in 
relation to hunting and ungulate abundance in northeastern Belarus during 1990-2000. Wildl Biol 9:103-111

Sillero-Zubiri C, Sukumar R, Treves A (2007) Living with wildlife: the roots of conflict and the solutions. In: MacDonald D, Service K (eds) Key topics in conservation biology. Oxford Press, Oxford, p 266-272

Similä T, Holst JC, Christensen I (1996) Occurrence and diet of killer whales in northern Norway: seasonal patterns relative to the distribution and abundance of Norwegian spring-spawning herring. Can J Fish Aquat Sci 53: 769-779

Smith JA, Mazumder D, Suthers IM, Taylor MD (2013) To fit or not to fit: evaluating stable isotope mixing models using simulated mixing polygons. Methods Ecol Evol 4: $612-618$

Stock BC, Semmens BX (2013) MixSIAR GUI user manual, version 1.0. http://conserver.iugo-cafe.org/user/brice. semmens/MixSIAR

Stock BC, Jackson AL, Ward EJ, Parnell AC, Phillips DL, Semmens BX (2018) Analyzing mixing systems using a new generation of Bayesian tracer mixing models. PeerJ 6:e5096

Stoddart LC, Griffiths RE, Knowlton FF (2001) Coyote responses to changing jackrabbit abundance affect sheep predation. J Range Manage 54:15-20

Tasker ML, Camphuysen CJ, Cooper J, Garthe S, Montevecchi WA, Blaber SJ (2000) The impacts of fishing on marine birds. ICES J Mar Sci 57:531-547

Tixier P, Gasco N, Duhamel G, Viviant M, Authier M, Guinet C (2010) Interactions of Patagonian toothfish fisheries with killer and sperm whales in the Crozet Islands Exclusive Economic Zone: an assessment of depredation levels and insights on possible mitigation strategies. CCAMLR Sci 17:179-195

Tixier P, Gasco N, Guinet C (2014) Killer whales of the Crozet Islands: photo-identification catalogue 2014. Centre d'Etudes Biologiques de Chizé-CNRS, Villiers en Bois

Tixier P, Authier M, Gasco N, Guinet C (2015) Influence of artificial food provisioning from fisheries on killer whale reproductive output. Anim Conserv 18:207-218

Tixier P, Gasco N, Duhamel G, Guinet C (2016) Depredation of Patagonian toothfish (Dissostichus eleginoides) by two sympatrically occurring killer whale (Orcinus orca) eco-

Editorial responsibility: Keith Hobson,

London, Ontario, Canada types: insights on the behavior of the rarely observed type D killer whales. Mar Mamm Sci 32:983-1003

*Tixier P, Barbraud C, Pardo D, Gasco N, Duhamel G, Guinet C (2017) Demographic consequences of fisheries interaction within a killer whale (Orcinus orca) population. Mar Biol 164:170

* Torres LG, Rayment W, Olavarría C, Thompson DR and others (2017) Demography and ecology of southern right whales Eubalaena australis wintering at sub-Antarctic Campbell Island, New Zealand. Polar Biol 40:95-106

Towers JR, Tixier P, Ross KA, Bennett J, Arnould JP, Pitman RL, Durban JW (2019) Movements and dive behaviour of a toothfish-depredating killer and sperm whale. ICES J Mar Sci 76:298-311

* Travers T, van den Hoff J, Lea MA, Carlyon K, Reisinger R, de Bruyn PN, Morrice M (2018) Aspects of the ecology of killer whale (Orcinus orca Linn.) groups in the nearshore waters of Sub-Antarctic Macquarie Island. Polar Biol 41:2249-2259

* Van Valen L (1965) Morphological variation and width of ecological niche. Am Nat 99:377-390

* Vehtari A, Gelman A, Gabry J (2017) Practical Bayesian model evaluation using leave-one-out cross-validation and WAIC. Stat Comput 27:1413-1432

*Votier SC, Furness RW, Bearhop S, Crane JE and others (2004) Changes in fisheries discard rates and seabird communities. Nature 427:727-730

*Weimerskirch H, Inchausti P, Guinet C, Barbraud C (2003) Trends in bird and seal populations as indicators of a system shift in the Southern Ocean. Antarct Sci 15:249-256

*Weimerskirch H, Le Bouard F, Ryan PG, Bost CA (2018) Massive decline of the world's largest king penguin colony at Ile aux Cochons, Crozet. Antarct Sci 30: 236-242

Woodroffe R, Thirgood S, Rabinowitz A (2005) People and wildlife: Conflict or co-existence? Cambridge University Press, Cambridge

Yukhov VL (1972) The range of fish of the genus Dissostichus (Fam. Nototheniidae) in Antarctic waters of the Indian Ocean. J Ichthyol 12:346-347

*Yurkowski DJ, Hussey NE, Semeniuk C, Ferguson SH, Fisk AT (2015) Effects of lipid extraction and the utility of lipid normalization models on $\delta^{13} \mathrm{C}$ and $\delta^{15} \mathrm{~N}$ values in Arctic marine mammal tissues. Polar Biol 38:131-143

Submitted: October 9, 2018; Accepted: February 12, 2019 Proofs received from author(s): March 14, 2018 